\title{
Pleural Mesothelioma Pathologic Regional Lymph Nodes TNM Finding v7
}

National Cancer Institute

\section{Source}

National Cancer Institute. Pleural Mesothelioma Pathologic Regional Lymph Nodes TNM

Finding v7. NCl Thesaurus. Code C88906.

A pathologic finding about one or more characteristics of pleural mesothelioma, following the rules of the TNM classification system as they pertain to staging of regional lymph nodes. 